\title{
キャピラリーバリア地盤の塩分上昇遮断機能 に及ぼす破砕貝殼微粒子の影響
}

\author{
小 林 董 1 ・松浦慶弥 2 ・松元和伸 $3 \cdot$ 森井俊広 4 \\ 1 正会員 茨城大学大学院教授 理工学研究科（干316-8511 茨城県日立市中成沢町4-12-1） \\ E-mail:kaoru.kobayashi.kk@vc.ibaraki.ac.jp \\ 2 茨城大学大学院 理工学研究科（干316-8511 茨城県日立市中成沢町4-12-1) \\ 3 正会員 飛島建設株式会社 技術研究所 第一研究室（干270-0222 千葉県野田市木間ケ瀬5472） \\ E-mail: kazunobu_matsumoto@tobishima.co.jp \\ 4 新潟大学自然科学系フェロー ( ( 950-2181 新潟県新潟市西区五十嵐 2 の町8050) \\ E-mail: morii@agr.niigata-u.ac.jp
}

\begin{abstract}
半乾燥地における塩類集積防止の有効な対策工の1つとして, 礫層とその上に砂層を重㸚たキャピラリ 一バリア地盤（以下， CB地盤と記す）がある. 半乾燥地における乾燥砂は, 乾燥や施工時の振動等で下 部の碩粒子間に混入しやすく，層状地盤を短〜長期的に保持することが極めて困難である．筆者らは，こ の課題に対し，礫材の代替材として破砕貝殼を用いることで， CB機能を保持すると共に，上部の砂が下 部の破砕貝殼層内へ混入することも同時に防止できることを明らかにしている。しかし，磁代替材として 破砕貝殼を用いた場合, 破砕貝殼の粒径により土壤水分特性曲線が異なるため, CB地盤による水分（塩 分）上昇遮断機能が異なる可能性がある. 本研究では, 破砕貝殼の粒径に着目し, 特に $2 \mathrm{~mm}$ 未満の破砕貝 殼の微粒子分が水分（塩分）上昇遮断機能に及ぼす影響を実験結果を基に明らかにした。
\end{abstract}

Key Words : capillary barrier, shell particles, salt damage, protection method

\section{1. はじめに}

塩類化の問題は，世界100ケ国以上で発生している11. 例えば，カザフスタンの乾燥地にあるアラル海2)，中国， タイ，メキシコ，オーストラリアなどである。これらの 国，地域によっては，持続的な農業開発に適した土地が 極めて少なく，未熟土の砂質土㙵も農地として利用する など，世界の水・食料問題にもつながる喫緊の課題とな っている3．塩類集積における塩害 $\rightarrow$ 植生枯死 $\rightarrow$ 砂漠化 のプロセスは，降水量と蒸発量の水収支のバランスが崩 れ，蒸発作用に起因寸る地盤内毛管作用が過度となって， 塩類含有地下水を地表付近に呼び込み，蒸発に伴う脱水 により塩類を析出させ，塩害をもたらすものである。こ の塩類集積に関する塩類移動のメカニズムは，例えば， 野村ら 4 にによる土/水/空気/溶解物質連成有限要素 (塩害過程) シミュレータにより, 地盤中の地下水に存 在していた塩類が，気候・気象条件に従い，土壤表面付 近に集積し，塩害が発生する様子が再現されている．ま た，土壤表面の乾燥に伴う塩類析出過程の解明について は，安部5が土性の異なるカラムを用いて塩類集積現象
を再現し，粘土含有量の違いによる土壤内の水分変化を 検討している. 藤巻らのは, 浅い地下水面を有する土壤 カラムからの蒸発に伴う塩類集積実験を行い, 移流分散 方程式の妥当性・適用性について明らかにしている.

一方，塩類集積の軽減と効果的な塩類化の防止対策の 一つとして，䃯層とその上に砂層を重㸚た土層によるキ ヤピラリーバリア（以下， CB と記す）を利用した塩類 集積防止工の検討が行われている7,8)，飯塚9はペーパー スラッジや浄水場発生污泥の処理を兼衫て，浄水污泥等 を $1,300^{\circ} \mathrm{C}$ 程度で焼成した保水性が低く, 透水性が高い 焼成セラミック材を用いたCBによる塩類化防止工を開 発した．しかし，井上占が指摘しているように，塩害対 象地域においてCB資材の入手の問題を解決寸る必要が あり, 現地で容易に入手でき, 特殊な技術や機器類を必 要としない施工法が必要不可欠である. なお，このCB は後述する図-1に示すような半乾燥地などにおいては, 貴重な降雨を効率よく地盤内に浸透した水を粗粒土層上 面の細粒土層下部に貯留する機能も合わせ持っている》

以上のことから，筆者らは塩害を被っている国，地域 の貝類の水揚げ量に着目した結果，多くの国で水揚げ量 が多いことを確認している10)。また，破砕した貝款は， 

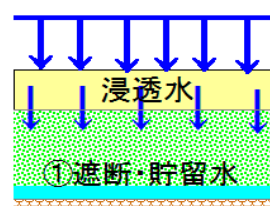

$(2)$ 管 1 , 遮断
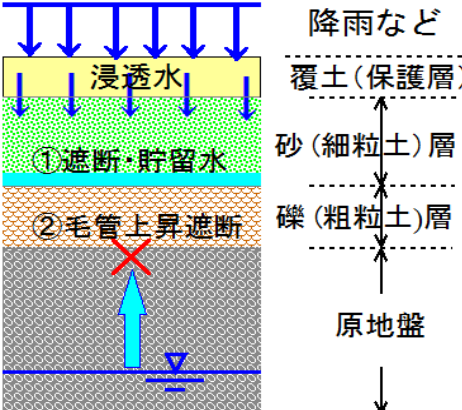

原地盤

図-1 CB 地盤による貯留と遮断機能のイメージ

CBを構成する礫代替材として有効利用できる11) と共に， 貝壳の種類による土袞水分特性曲線（Soil Water Characteristic Curve，以下SWCCと記す）の違いが無いことから ${ }^{12)}$, 塩害等の対象地で入手・調達しや寸い貝款をCB地盤に 活用できる.しかし，破砕貝款の粒径によりSWCCが大 きく異なる12)ことから，CB地盤内の地下水上昇遮断機能 にも影響を及ぼすものと考えられる.

本研究は, 現地で比較的に入手が容易な水産系副産物 である貝殼を砂代替材として用いたCB（以下，貝殼型 CBと記す）により，効果的な塩類集積防止策を開発す ることを目的に，鉛直一次元円筒装置（内径 $20 \mathrm{~cm}$ ）を 用いて，破砕貝殼の粒径をパラメータにして地下水から の水分（塩分）上昇遮断機能の違いを実験的に検証する. 特に，貝殼を破砕する時に生じる貝殼微粒子分が，水分 （塩分）上昇遮断機能に及ぼす影響を明らかにする.

\section{2. $\mathrm{CB}$ の水分（塩分）上昇遮断機能について}

$\mathrm{CB}$ の構造は，砂層（相対的に細粒な土層）とその下 部に碅層（相対的に粗粒な土層，または破砕貝殼層）を 重祆た単純な土層で，互いの透水性，保水性の相対的な 違いにより，CB機能を発揮する．降雨や地表かんがい により不飽和浸透が生じると，このCB機能により砂層 と碩層などの境界面の上部で浸透水が保持・貯留され, 下部の碅層などへの水分移動が抑制・防止される. 加え て，CB機能としては，地表面下にある塩類含有地下水 の毛管上昇を遮断することで，地下水からの供給に由来 する塩類集積を防止することができる（図-1）。

\section{3. 重機で破砕した貝殼の粒径及び粒度分布}

塩害を受けている国，地域において，実際の施工を想 定して貝殼CBを構築する場合には，前述したように資

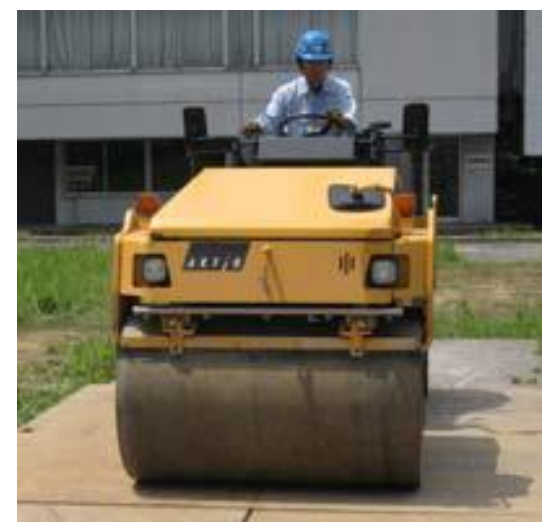

写真-1 貝殼破砕時に用いた鉄輪の振動ローラ

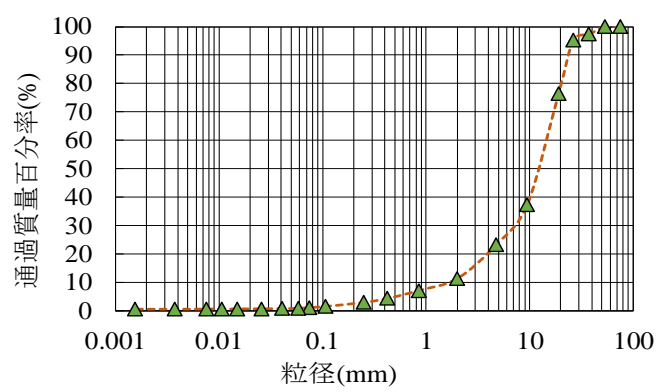

図-2 重機破砕した貝殼の粒径加積曲線

材や機器の調達が容易で，特殊な技術や装置などを必要 としない施工方法が必要不可欠であると考えられる。こ のことから，破砕機などの特殊装置を用いるのではな く, 実際の施工を想定して, 写真-1に示寸比較的軽量で 運搬しや寸い鉄輪の振動ローラ（重量 4 ton）を用いて破 砕と転圧（以下，重機転圧破砕と記す）を同時に行える 方法とした．振動ローラにより破砕した貝殼（以下，重 機転圧破砕貝殼と記す）の粒度特性を把握するために, 貝殼の撒き出し厚さと振動ローラによる転圧回数を変化 させた破砕実験を行った ${ }^{13}$. 実験に用いた貝殼は，大量 に入手が可能なホタテ貝（青森産）とし，設定した撒き 出し厚さになるように貝殼を設置し, 振動ローラを用い て破砕した．その後，破砕した貝殼をスコップで採取し 粒度試験を行った，振動ローラを用いた各種条件下での 貝殼の破砕実験結果を基に，施工性などを考慮して，撒 き出し厚さは $20 \mathrm{~cm}$, 転圧回数は 12 回が適切と判断され た ${ }^{13)}$. 上記条件で破砕した重機転圧破砕貝殼のふるいを 用いた粒度試験結果（粒径加積曲線）は，図-2に示寸通 りであり, 平均粒径 $D_{50}$ が $12.9 \mathrm{~mm}$, ふるい目の $2 \mathrm{~mm}$ 未満 の微粒子分も 10 数\%含まれている.

以上より，破砕貝款の $2 \mathrm{~mm}$ 未満の微粒子分は，毛管 上昇高も比較的高く, 保水性もあり, 微粒子分が集中す る領域が生じた場合には，本来発揮される貝殼型 $\mathrm{CB}$ の 機能が損なわれる可能性がある. このことから, 以下の 確認実験を行い微粒子分が水分（塩分）上昇遮断機能に 及ぼす影響について検証した，なお，貝殼の破砕方法は SWCCに及ぼす影響が無いことを確認済みである12). 


\section{4. 貝殼型CBによる水分（塩分）上昇遮断機 能の確認実験}

\section{(1) 試料}

貝殼型 CB 地盤を構成する試料は，鹿島珪砂 6 号（以 下，珪砂 6 号と記す）と貝殼である。貝殼は，ホタテ貝 (青森産) を用い， $80^{\circ} \mathrm{C}$ 乾燥炉で 24 時間乾燥し，そ の後自然大気中で 24 時間以上静置して, 常温になった 後に破砕した．実験に用いた破砕貝殼は，振動ローラで 破砕した時の粒径加積曲線を有する貝殼試料と微粒子

(ここでは，2mm ふるい目を通過したもの）のみに粒 度調整した貝殼試料の 2 種類を用いた。

珪砂 6 号と破砕貝殼（2 種類）の土の粒度試験（JIS A 1204）により得られた粒径加積曲線および土の透水試験

（JIS A 1218）で求めた飽和透水係数 $K_{\mathrm{s}}$ を含めた物理的 性質は，図-3および表-1に示寸，なお，飽和透水係数 $K_{\mathrm{s}}$ は，後述する確認実験時と同様の乾燥密度になるように 供試体を作製した上で求めた。また，図-4 に示寸内径 $10 \mathrm{~cm}$ で，高さ $2.5,5.0$ および $10.0 \mathrm{~cm}$ の塩ビ製のリング を積夕重㸚た，全高 $90 \mathrm{~cm}$ の一次元円筒装置（土柱法の 装置）により，珪砂 6 号と破砕貝殼（2 種類）の SWCC を排水・吸水過程共に，自然乾燥状態を初期状態として 求めた（図-5および図-6）。なお，SWCCにおいて，供 試体から排水（または供試体に吸水）が生じる場合，こ の過程を排水（または吸水）過程と呼ぶ ${ }^{14}$.

\section{(2) 実験概要}

写真-2および図-7 (b)に示すような下端部に注水・排水 口を有する鉛直一次元円筒装置（内径 $20 \mathrm{~cm} ，$ 塩ビ製) を定水位タンク内に静置する，次に，定水位状態の基で 円筒装置内の試料の水分移動が完全に定常状態になるま で（本実験では，水位を上昇させた段階（実験開始）か ら 5 日間），体積含水率 $\theta$ の経時変化を土壌水分センサ 一（EC-5，METER 社製）で測定し，毛管上昇に伴う土 中内の水分移動・遮断機能を観察した.

実験は，次の 3 ケースについて実施した。 すなわち， 図-7 の層厚 $8 \mathrm{~cm}$ の試料 $\mathrm{A}$ の部分を，ケース 1 : 珪砂 6 号 の土層, ケース 2 : 重機転圧破砕した後にふるいを用い

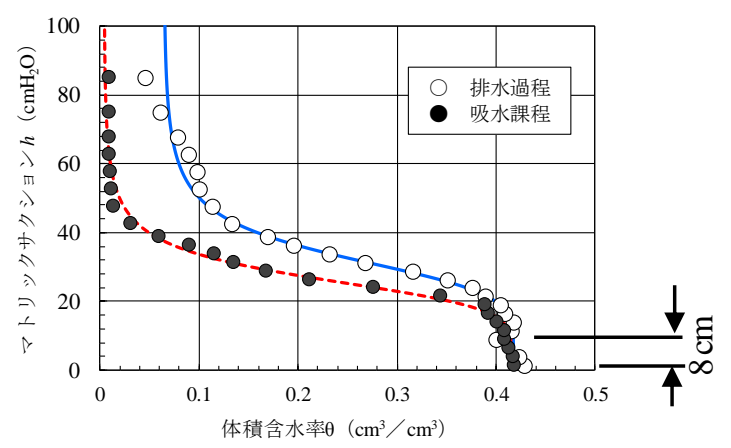

図-5 珪砂 6 号の SWCC

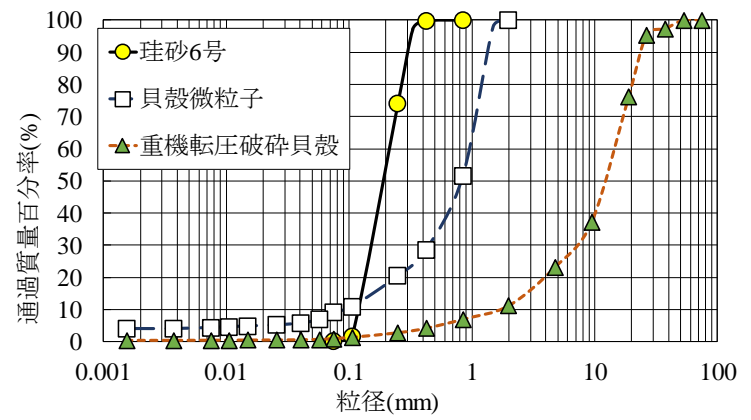

図-3 試料の粒径加積曲線

表-1 試料の物理的性質

\begin{tabular}{l|c|c|c|c|c}
\hline \multicolumn{2}{l|}{} & 単位 & 珪砂6号 & 貝款微粒子 & $\begin{array}{l}\text { 重機転圧 } \\
\text { 破砕貝款 }\end{array}$ \\
\hline 土粒子密度 & $\rho_{\mathrm{s}}$ & $\mathrm{g} / \mathrm{cm}^{3}$ & 2.73 & 2.70 & 2.70 \\
\hline $50 \%$ 粒径 & $D_{50}$ & $\mathrm{~mm}$ & 0.194 & 0.814 & 12.9 \\
\hline 均等倸数 & $U_{\mathrm{c}}$ & - & 1.74 & 10.9 & 8.56 \\
\hline 最大乾燥密度 & $\rho_{\mathrm{dmax}}$ & $\mathrm{g} / \mathrm{cm}^{3}$ & 1.540 & - & - \\
\hline 最適含水比 & $w_{\mathrm{opt}}$ & $\%$ & 12.3 & - & - \\
\hline 最大間隙比 & $e_{\max }$ & - & 1.040 & 1.804 & 1.687 \\
\hline 最小間隙比 & $e_{\min }$ & - & 0.638 & 0.809 & 1.029 \\
\hline 設置時乾燥密度 & $\rho_{\mathrm{d}}$ & $\mathrm{g} / \mathrm{cm}^{3}$ & 1.386 & 1.221 & 1.090 \\
\hline 設置時含水比 & $w$ & $\%$ & 12.3 & 0.2 & 0.2 \\
\hline 透水係数 & $K_{\mathrm{s}}$ & $\mathrm{m} / \mathrm{s}$ & $1.62 \times 10^{-4}$ & $7.13 \times 10^{-6}$ & $3.27 \times 10^{-3}$ \\
\hline
\end{tabular}

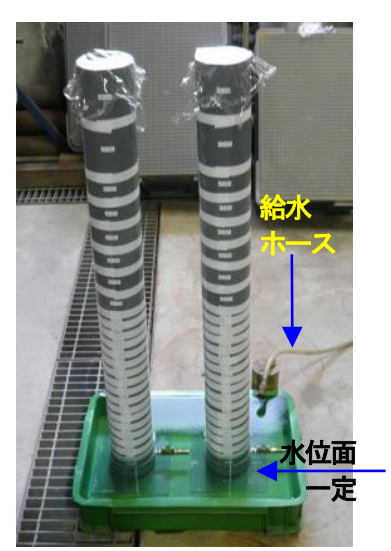

（a）試験状況（吸水過程）

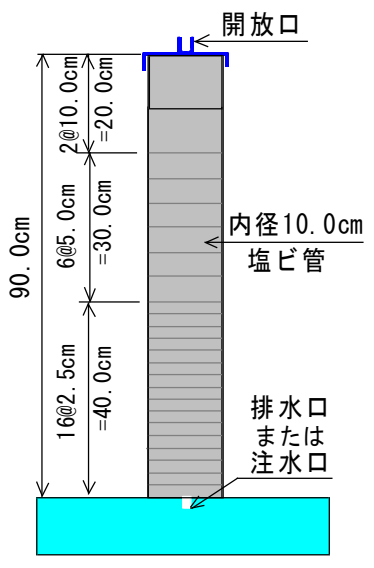

(b) 装置概要
図-4 土柱法に用いた一次元円筒装置の概要

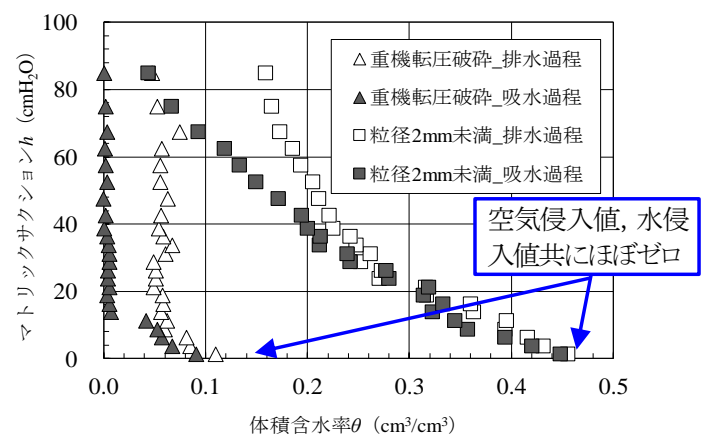

図-6 粒径の異なる 2 種類の破砕貝款の SWCC 


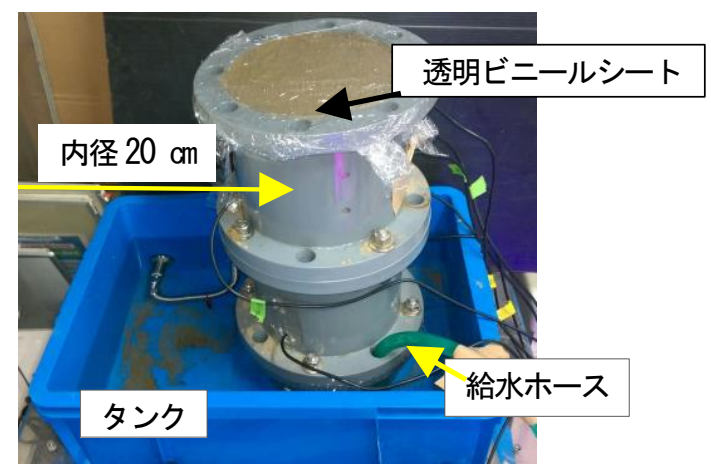

写真-2 一次元円筒装置（塩ビ製）の外観

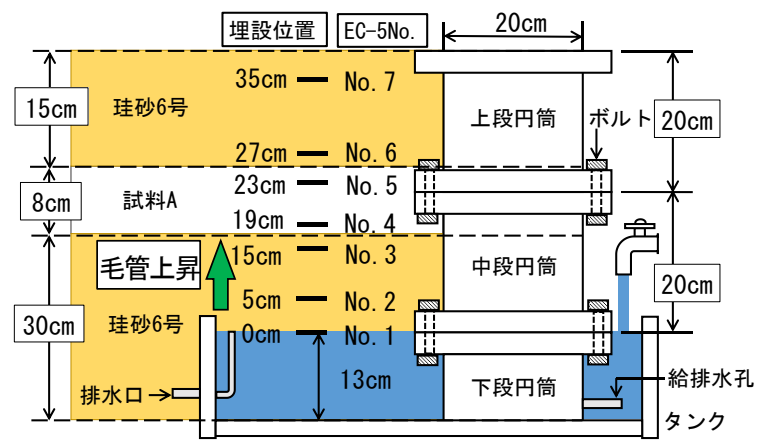

(a)センサー埋設位置と番号 (b)円筒装置

図-7 センサーの埋設位置と番号及び各土層の厚さ

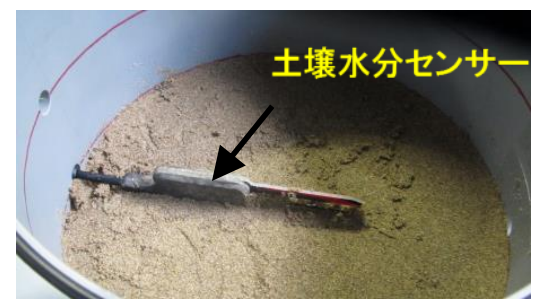

写真-3 装置内部の土袞水分センサーの設置状況

て $2 \mathrm{~mm}$ 未満の微粒子分だけに粒度調整した破砕貝殼層, およびケース 3 : 振動ローラで破砕した時の粒径加積曲 線を有する破砕貝殼層としたものである.

供試体は，図-7(b) に示寸内径 $20 \mathrm{~cm}$ ，高さ $53 \mathrm{~cm}$ （最 下段のリング容器高さは $13 \mathrm{~cm}$, その上部 2 段は各 $20 \mathrm{~cm}$ ) の塩ビ製の一次元円筒装置で，まず最適含水比（ $w_{\text {opt }}$ $=12.3 \%$ ）に調整した珪砂 6 号を, 所定の乾燥密度（締固 め度 $D c=90 \%$ ）になるように，手製の突固め板で締固 めて作製した，供試体作製時には，各砂層間の密着性向 上などを考慮し，各砂層上面をへラで粗し，その上に試 料を入れて締固め, 順次上層を構築した. 珪砂 6 号は厚 さ $5 \mathrm{~cm}$ を基本として順次締固め作業を繰り返し，ケー スごとに所定高さの供試体を完成させた。 また，ケース 2，3の破砕貝殼層は所定の位置に厚さ $8 \mathrm{~cm} /$ 層で締固め仕 上げた. 供試体完成後は, 供試体内の水分の蒸発を防ぐ ために，一次元円筒装置上面に透明ビニールシートを被 せ 3 時間静置した. その後, 埋設した土畩水分センサー の值に変動がないことを確認した上で実験を開始した.

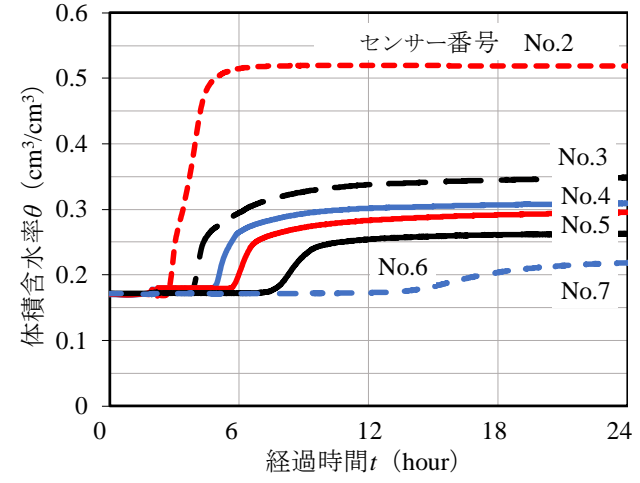

図-8 体積含水率 $\theta$ の経時変化（ケース 1)

毛管上昇に伴う円筒装置内土中の水分（体積含水率 $\theta$ ) 変化を測定するための，土壌水分センサーは供試体作製 時に所定の高さに溝堀りを行い設置した（写真-3）。土 壌水分センサ一周辺の埋め戻しは，センサ一周りに空隙 を残さないように慎重に突き棒で締め固めた。 土㙵水分 センサー7 台の設置位置と各センサー番号（下部より No.1〜No.7) を図-7(a)に示す. また, 試料 A の設置位置 は，図-7(a)に示寸ように 3 ケースともに，一次元円筒装 置底版より $30 \sim 38 \mathrm{~cm}$ （層厚 $8 \mathrm{~cm}$ ） とし，設定水位面か ら試料 $\mathrm{A}$ 層の下面までは $17 \mathrm{~cm}$ とした.

\section{(3) 実験結果}

本実験では，貝殼型CBを設置することで毛管上昇に よる水分移動および庶断機能を確認する. 水分移動・遮 断機能の確認は，土中に7台埋設した土壌水分センサー の挙動を基に評価した．なお，実験時には，供試体上部 の乾燥を防止するために，透明ビニールシートを供試体 上面に直接置いた.

図-8には，ケース 1 の実験開始直後の体積含水率 $\theta$ の経 時変化を示す，センサ一番号No.2が地下水面位置から最 も近い位置にあるセンサーであり，所定の地下水位に設 定した場合にはいち早く反応寸ると共に，体積含水率 $\theta$ の上昇量は最も大きい（含水比, 飽和度が高い) ことが 分かる，一方，最も上部に位置するセンサ一番号No.7は， 地下水位面からの距離があるため，毛管上昇で上昇して くる水分の影響は最も遅く, 体積含水率 $\theta$ の変化量も小 さいことが分かる．以上より，毛管上昇によって土㙵水 分センサーが下部（センサー番号No.2）より上部（セン サ一番号No.3 $\rightarrow$ No.7） に向かって順次反応しており，一 次元円筒装置内の土中を上向きに浸透し, 水分が上昇し ていることが確認できる.

図-9(a)〜(c)は，ケース1〜ケース3の供試体作製から水 分移動がなくなる定常状態（実験開始から5日間）にな るまでの体積含水率 $\theta$ 経時変化を示したものである.

図-9(a)のケース1については，センサー番号No.2の測 定值が最も早く反応しており，毛管上昇の影響をいち早 く受けていると共に, 体積含水率 $\theta$ の変化量が最も大き いことがわかる．また，各センサーについては，地下水 


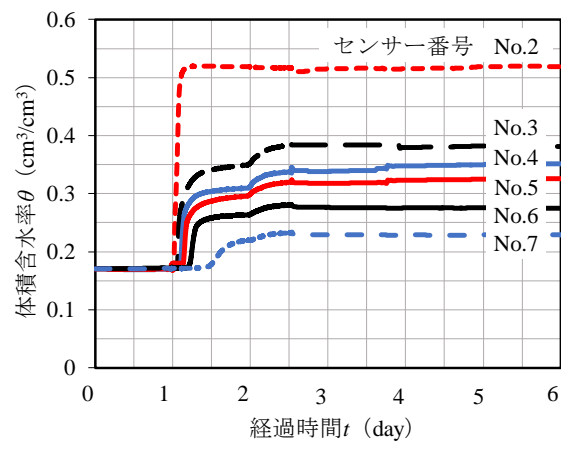

(a) ケース $1:$ 珪砂 6 号 厚さ $8 \mathrm{~cm}$

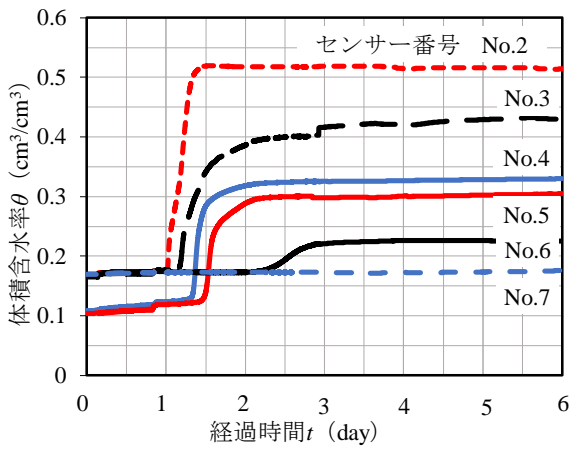

(b) ケース 2 : 貝款微粒子 厚さ $8 \mathrm{~cm}$

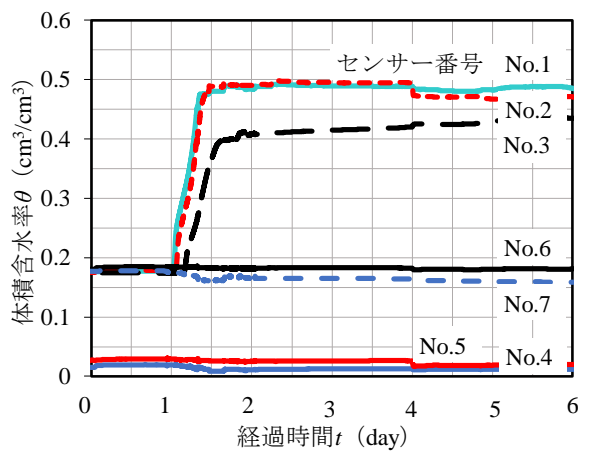

(c) ケース 3: 重機転圧破砕貝款 厚さ $8 \mathrm{~cm}$

図-9 各供試体の体積含水率 $\theta$ の経時変化

位面からの距離にしたがって反応時間が遅くなっている と共に，体積含水率 $\theta$ の変化量も小さくなっている．加 えて, 最上部に位置するセンサ一番号No.7の体積含水率 $\theta$ も変化しており，毛管上昇に伴う水分移動の影響が最 上部のセンサ一位置まで達していることが確認できる.

このことから，貝殼型CBを設置していないケース1につ いては，全ての土壊水分センサーに変化が見受けられる ことから，毛管上昇に伴う水分移動が円筒装置の上部ま で確認できると共に，水分上昇を遮断するような体積含 水率 $\theta$ の挙動は全く見受けられなかった.

図-9(b)の破砕貝殼の微粒子分の夕で貝殼型CB地盤を 構築した場合，センサー番号のNo.2〜No.6までは前記の ケース1と同様に，体積含水率 $\theta$ に変化が見受けられ破砕 貝殼層上部まで水分の移動が確認できるものの，センサ 一番号No.7の体積含水率 $\theta$ は僅かに上昇しているものの, 実験開始前とほとんど変化が無かった。これは，微粒子
分のみの破砕貝殼層の透水係数がケース 1 の珪砂 6 号の透 水係数に比較して2オーダー程度小さいことから, 破砕 貝殼層を浸透・通過する水分量が非常にゆっくりしてお り，センサー番号No.7の体積含水率 $\theta$ 懄しか上昇 ・ 変化していないものと推察される，なお，本実験は実験 開始から5日間しか測定してしていないことから，更に 長期間測定を継続した場合には，センサ一番号No.7の体 積含水率 $\theta$ も徐々に上昇するものと考えられる.

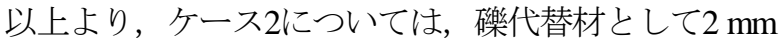
未満の微粒子分のみの破砕貝殼層を設けた貝殼型CB地 盤では，ケース1に比較してセンサー番号No.6の体積含 水率 $\theta$ 反応するまで時間や体積含水率 $\theta$ の変化量も小さ いものの， $\mathrm{CB}$ 機能は十分には発揮されておらず，ケー ス1同様に毛管上昇に伴う水分移動が貝殼型CB地盤の上 部まで確認できることから，ケース2の貝殼型CB地盤で は水分上昇を遮断するような体積含水率 $\theta$ の挙動は見受 けられなかった。

一方，図-9(c)のケース3においては，前記のケース1お よびケース 2 に比較して決定的に異なる点は, 破砕貝殼 層内のセンサー番号No.4，No.5およびその上部に位置す るセンサー番号No.6，No.7については，実験開始から5 日経過後においても体積含水率 $\theta$ に応が見受けられず, まったく変化していないことが確認できる. なお， セン サ一番号No.2については，地下水面より上に埋設してい るが，図-5のSWCCから水侵入值（吸水過程から求まる 飽和状態近傍にある垂直に立ち上がる部分の高さに相当 する值で珪砂6号は約 $8 \mathrm{~cm}^{11)}$ ) より低い位置にセンサー 番号No.2（地下水面より $5 \mathrm{~cm}$ 上）が埋設されており，ほ ぼ飽和状態と考えられ，センサー番号No.1とほぼ同じ值 になったことが伺える．他ケースも同様の傾向であった．

以上より，振動ローラで破砕した時の粒径加積曲線を 有する破砕貝殼を用いた貝殼型CBは，破砕貝殸層下端 の層境界面でCB機能を発揮し，下部から供給される毛 管上昇による水分移動が遮断されていることが確認でき た。 これにより，ケース3については， $2 \mathrm{~mm}$ 未満の微粒 子分を10数\%含んでいるものの, 地下水からの供給に由 来する塩類集積を防止できることを確認した.

\section{5. まとめ}

本研究は，破砕貝殼の粒径（粒度分布）に着目し，特 に2 mm未満の破砕貝殼の微粒子分が水分（塩分）上昇 遮断機能に及ぼす影響を把握するために一次元円筒実験 を行った結果, 以下の知見が得られた。

1) ケース 1 同様に磪代替材として $2 \mathrm{~mm}$ 未満の微粒子分の みの破砕貝殼層を設けた貝殼型CB地盤（ケース2）は， 
水分上昇を遮断するような体積含水率 $\theta$ の挙動は見受

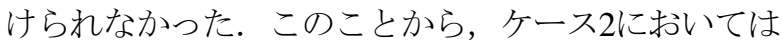
$\mathrm{CB}$ 機能が十分発揮されないことが明らかになった.

2) 振動ローラで破砕した時の粒径加積曲線を有する破砕 貝殻を用いた貝殼型CB地盤（ケース3）は，2 mm未満 の微粒分を10数\%含んでいるものの，破砕貝殻層下端 の層境界面でCB機能を発揮し，毛管上昇による下部 地下水からの水分移動が遮断されることが確認できた. したがって，地下水からの供給に由来する塩類集積を 防止できることが明らかになった。

3)貝殼型CB地盤は，破砕貝殼の粒径により図-6に示す様 に保水性や表-1に示方飽和透水係数（透水性）が大き

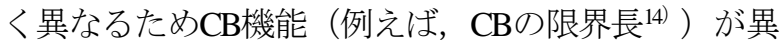
なる．実施工時の締固め破砕時に，微粒子分が集中寸 る様なことが生じた場合には，本来発揮される貝殼型 $\mathrm{CB} の$ 機能が損なわれる可能性があることから，CB地 盤の品質を確保するための施工管理が必要である.

謝辞：本研究は，H29 年度 JSPS 科研費 $16 \mathrm{~K} 06486$ 並びに, 茨城大学推進研究プロジェクトの援助を受けて行った. また，室内土質試験では，(有)TNS 田口勝夫氏，染谷昇 氏に多大なご協力を頂いた。 ここに記して謝意を表す.

\section{参考文献}

1) 井上光弘：論説 塩類化の現状と除塩技術, 地盤工 学会誌, Vo.60, No.1, pp.12-15, 2012.

2) 井筒 暉 : シリーズ「乾燥地の潅溉農業と水環境」, 乾燥地における潅溉農業の進展と環境問題, 水文・ 水資源学会誌, Vol.11, No.4, pp.398-406, 1998.

3) 宮㠃 毅: 総説 水・食糧問題と地盤工学, 地盤工学 会誌, Vol.60, No.1, pp.2-6, 2012.

4) 野村瞬, 河井克之, 金澤伸一, 橘伸也, 飯塚 敦 : 土 / 水 /空気/溶解物質連成問題の定式化とその応用, 神戸大学都市安全研究センター研究報告, 第 15 号, pp.21-28, 2011.

5) 安部征雄 : 土性の相異と塩類集積特性との関係 - 塩類 集積の機構とその対策に関する土壌物理学的研究 ( I ) - ，農業土木学会論文集，Vol.94，pp.32-40，1981.

6) 藤巻晴行, 取手伸夫, 山本太平, 井上光弘 : 浅い地 下水面を持つ砂丘砂カラムからの土壤面蒸発に伴う 溶質移動, 農業土木学会論文集, No.190, pp.77-86, 1997.

7) 星野麻衣子, 傳田 彩, 中野 有里加, 森井俊広 : 土の キャピラリーバリアを利用したかんがい水の効率的 な利用と土壤塩分化の抑制, 新潟大学農学部研究報 告, Vol67, No.1, pp.65-76, 2014.

8) Guo,G.,Araya,K.,Shibutani,Y.,Zhang,H.,Ohomiya,K. and Matsuda,J. : Improvement of salt-affected soils, Part 1, Interception of capillarity, Biosystems Engineering, Vol.94, No.1, pp.139-150, 2006.

9) 飯塚 敦 : 塩害・地盤変状発生機構の解析と環境負荷 污泥焼成物を用いた防止技術の開発, 科学研究費助 成事業（科学研究費補助金）研究成果報告書，様式 C-19, pp.1-5, 2012.

10）小林 薰, 松元和伸, 森井俊広 : 貝款を有効利用したキャ ピラリーバリアによる塩害防止策に関する基礎的研究, 土木学会論文集 B3（海洋開発），Vol.71，No.2，pp.I_874 I_879, 2015.

11) 中房 悟, 小林 董, 松元和伸, 森井俊広 : 貝殼を再利 用したキャピラリーバリア地盤の大型土槽実験によ る限界長の評価, 土木学会論文集 C (地圈工学), Vol.69, No.1, pp.126-139, 2013.

12) 中房 悟, 小林 薰, 森井俊広, 松元和伸 : 水産系副産 物（貝殼）を用いた砂混入防止型キャピラリーバリ ア地盤に関する検討，土木学会論文集 B3（海洋開 発）, Vol.68, No.2, pp. I_462- I_467, 2012.

13）松元和伸，小林薰，森井俊広 : 建設重機により破砕した 貝殼のキャピラリーバリア碩代替材としての適用性，第 57回地盤工学シンポジウム論文集，地盤工学会，pp.235238, 2012

14) 森井俊広 : 土のキャピラリー・バリア，地盤工学会 誌, Vol.59, No.2, pp.50-51, 2011.

(2018.2.8 受付)

\title{
EFFECT OF CRUSHED SHELL FINE PARTICLES ON PROTECTION METHOD OF SALT DAMAGE OF CAPILLARY BARRIER OF SOIL
}

\author{
Kaoru KOBAYASHI, Keiya MATSUURA, Kazunobu MATSUMOTO \\ and Toshihiro MORII
}

One effective countermeasure to prevent salinization in semi-arid lands is capillary barriers (CB), where gravel layers meet sand layers. Dry sand in semi-arid lands easily mixes between gravel particles due to drying and vibration during construction, etc. It is extremely difficult to retain layered ground over the short or long term. The authors clarified that by using crushed shells as a substitute for gravel, it is possible to maintain the $\mathrm{CB}$ function as well as preventing the upper sand from mixing into the lower crushed shell layer at the same time. However, when crushed shells are used as a substitute for gravel, since the soil water characteristic curve varies greatly depending on the particle size of the crushed shell, there is the possibility that the salinity (moisture) blocking function of the CB may be significantly impaired. Therefore, in this study, by focusing on the particle diameter of the crushed shells, the influence of fine crushed shell particles of less than $2 \mathrm{~mm}$ on preventing salinization was clarified experimentally. 